Research Paper

\title{
Identification of the constraints faced by the college and the farmers' of the vicinity in the cultivation of Aloe-vera crop
}

\section{RAJU CHOUDHARY AND PRADEEP KUMAR}

See end of the paper for authors' affiliations

Correspondence to : RAJU CHOUDHARY Department of Agriculture Economics, S.K.N. College of Agriculture, JOBNER (RAJASTHAN) INDIA Email: pooniyaraju30@ gmail.com

\section{Paper History :}

Received : 08.03.2017;

Revised : 26.07.2017

Accepted : 06.08.2017
Abstract : Aloe (Aloe vera) is an important and traditional medicinal plantbelonging to the family Liliaceae. Results of opinion survey revealed that the major constraints were lack of technical advice for Aloe vera cultivation, scarcity of packing material, lack of processing unit, high cost of improved variety suckers, low prices of Aloe vera crop and less interest of local leaders for Aloe vera cultivation.

KEY Words : Aloe vera, Liliaceae, Constraints, Lack of technical advice (JEL codes: A1, A14,A12,A11, A10, B40, B41)

How To Cite This PAPer : Choudhary, Raju and Kumar, Pradeep (2017). Identification of the constraints faced by the college and the farmers' of the vicinity in the cultivation of Aloe-vera crop. Internat. Res. J. Agric. Eco. \& Stat., 8 (2) : 310-314, DOI : 10.15740/HAS/IRJAES/8.2/310-314. 